\title{
SOUTHEAST ASIA
}

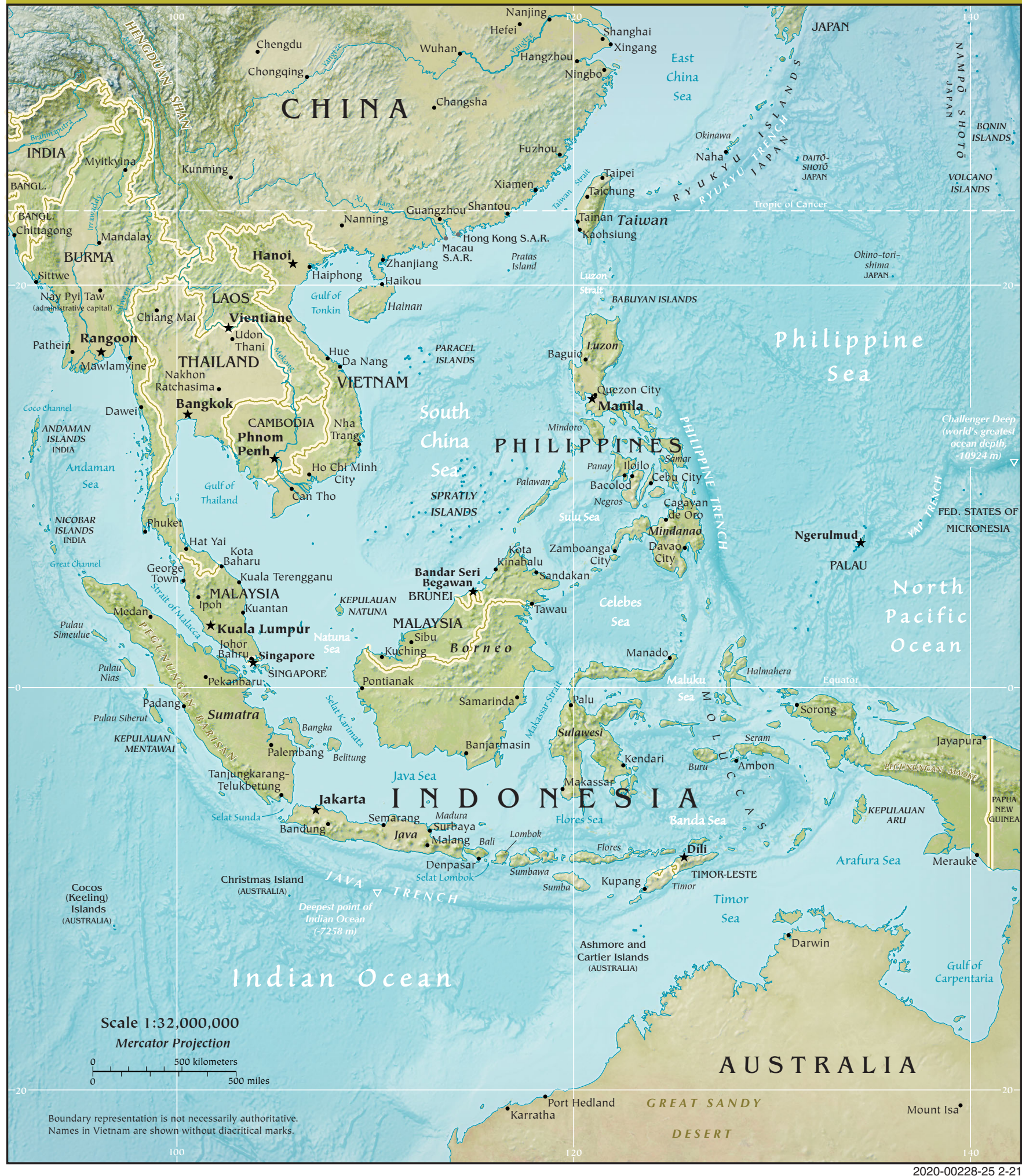

